\title{
Overweight in men and women among urban area residents: individual factors and socioeconomic context
}

\section{Excesso de peso em homens e mulheres residentes em área urbana: fatores individuais e contexto socioeconômico}

\section{Sobrepeso en hombres y mujeres residentes en zonas urbanas: factores individuales y contexto socioeconómico}

\author{
Roseli Gomes de Andrade 1 \\ Otaviana Cardoso Chaves 1 \\ Dário Alves da Silva Costa 1,2 \\ Amanda Cristina de Souza Andrade 1,2 \\ Stephanie Bispo 1 \\ Monica Faria Felicissimo 1 \\ Amélia Augusta de Lima Friche 1,2 \\ Fernando Augusto Proietti 3,4 \\ César Coelho Xavier 1,4 \\ Waleska Teixeira Caiaffa 1,2
}

\footnotetext{
1 Observatório de Saúde Urbana de Belo Horizonte, Universidade Federal de Minas Gerais, Belo Horizonte, Brasil.

2 Faculdade de Medicina, Universidade Federal de Minas Gerais, Belo Horizonte, Brasil.

3 Centro de Pesquisas René Rachou, Fundação Oswaldo Cruz, Belo Horizonte, Brasil 4 Faculdade de Saúde e Ecologia Humana, Vespasiano, Brasil.

Correspondence R. G. Andrade Observatório de Saúde Urbana de Belo Horizonte, Universidade Federal de Minas Gerais.

Av. Professor Alfredo Balena 190, sala 730, Belo Horizonte, MG 30130-100, Brasil. roselidd@gmail.com
}

\begin{abstract}
The present study aimed to evaluate factors associated with overweight among adults living in urban areas, with the income of the census tract as a context variable. The survey assessed individuals from two health districts of Belo Horizonte, Minas Gerais State, Brazil. Excess weight was determined by body mass index $>25 \mathrm{~kg} / \mathrm{m}^{2}$. Multilevel logistic regression was used. The sample comprised 2,935 individuals aged 20 to 60 years. The prevalence of overweight was $52.3 \%$ (95\%CI: 49.9-54.8), similar between men and women. Higher schooling proved to be protective against overweight in women and a risk for men. Living in census tracts with higher income was associated with excess weight only in males. Report of the consumption of diet soft drinks was positively associated with overweight in both sexes. The occurrence of this event seems to be influenced by different factors or to interrelate differently in men and women.
\end{abstract}

Obesity; Income; Socioeconomic Factors; Urban Health

\section{Resumo}

O presente estudo objetivou avaliar os fatores associados ao excesso de peso em adultos residentes em área urbana, considerando a renda do setor censitário como variável de contexto. O inquérito avaliou indivíduos de dois distritos sanitários de Belo Horizonte, Minas Gerais, Brasil. O excesso de peso foi determinado pelo índice de massa corporal $>25 \mathrm{~kg} / \mathrm{m}^{2}$. Foi utilizada regressão logística multinível. A amostra foi constituída por 2.935 in divíduos de 20 a 60 anos. A prevalência de excesso de peso foi de 52,3\% (IC95\%: 49,9-54,8), semelhante entre homens e mulheres. Enquanto a alta escolaridade revelou-se protetora para o excesso de peso em mulheres e de risco para homens, residir em setor censitário com maiores níveis de renda associou-se apenas no sexo masculino. O relato do consumo de refrigerantes dietéticos foi associado positivamente ao excesso de peso em ambos os sexos. A ocorrência desse evento parece ser influenciada por fatores distintos ou se inter-relacionar de forma diferente, em homens e mulheres.

Obesidade; Renda; Fatores Socioeconômicos; Saúde Urbana 


\section{Introduction}

Obesity is an important public health problem, as it is related to the development and progression of other chronic diseases, including cardiovascular conditions, diabetes, musculoskeletal disorders and some types of cancer. Its prevalence has grown in both, developing and developed countries $1,2,3,4$.

The results of the Household Budgets Sur$v e y$, carried out in 2008-2009, reveal that half of the Brazilian population is overweight. In men, overweight and obesity were more frequent in urban areas, whereas these differences, in terms of location of residence, were less striking for women 5 .

It is known that obesity is a result of different factors that seem to include interactions between genetic susceptibility and environmental stimulation 6 . From the perspective of physiology, weight gain occurs when the energy balance is positive, this means, when calorie intake is higher than calories burned. In addition to genetic and metabolic factors, characteristics of the environment where people live have been ascribed as playing a relevant role in the etiology of chronic diseases, since they can influence life habits, healthy or not 7 .

The main proximal determinants - food intake and physical activity - are influenced by other factors, such as family and neighborhood, which, in turn, may determine access and individual preferences 8 .

It is to be mentioned that the socioeconomic level of the neighborhood has been considered one of the factors related to obesity epidemics. Studies have reported that subjects residing in more socioeconomically deprived neighborhoods have less availability and access to healthy food, and little chance to practice physical activities 9,10,11.

Furthermore, it is known that overweight is also influenced by socioeconomic status, in addition to sex and age 8 . In developed countries, obesity is inversely associated to socioeconomic status among women, and less consistently among men, whereas in developing countries there is a direct association 12, despite the fact that the possible mechanisms through which these differences occur are not clear.

In Brazil, most studies that investigated overweight have focused only on features related to individuals, which is not enough to explain obesity epidemics at a population level. Therefore, the present study attempted to assess factors related to overweight in adult residents of urban areas, considering the income of the census tracts as a context variable. Knowing the determinants that play a role in the overweight of women and men is an important step for the development of more effective strategies in the prevention/reversal of this established epidemic.

\section{Methods}

\section{Study and sample design}

This study is part of an investigation called The BH Health Study, in which 4,048 individuals residing in 149 census areas of two (Oeste and Barreiro) out of nine health districts of the city of Belo Horizonte, Minas Gerais State, Brazil. The subjects were selected because they represented intra-urban inequalities of the city of Belo Horizonte in terms of demographic, socioeconomic, and health indicators that are proxies of the health inequalities of the population.

The survey was originally carried out with residents aged 18 and over, with the purpose of investigating the social determinants of health, and characterizing the way of living, lifestyle and healthy habits. According to a detailed description by Ferreira et al. 13, the sampling process used was the three-stage composite (drawing of census tract within the health district; drawing of household, and drawing of an individual from the household). For this analysis, adult individuals aged 20 to 60 years of both sexes were selected $(\mathrm{n}=3,129)$.

\section{Data collection}

Data were collected in 2008 and 2009, after training for the interview, anthropometry, and conducting a pilot study to test the applicability of the instruments and fieldwork logistics. The study questionnaire included the following modules: information about the household, habits and behavior, sociodemographic data, social and health determinants. After completion of the questionnaire, the subjects' weight, height and waist circumference were measured according to standardized techniques. The instruments used were a Tanita BC-553 scale (Tanita Corporation of America Inc., Arlington Heights, United States), WCS/Wood Compact mobile stadiometer (Cardiomed), and inelastic measuring tape 13,14.

\section{Description of the variables}

The dependent variable, overweight, was defined according to the body mass index (BMI = weight/ height ${ }^{2}$ in $\mathrm{kg} / \mathrm{m}^{2}$ ), being classified as "eutrophic" (BMI ranging from 18.5 and $25.0 \mathrm{~kg} / \mathrm{m}^{2}$ ), and "overweight" (BMI above $25.0 \mathrm{~kg} / \mathrm{m}^{2}$ ), in accordance to 
values proposed by the World Health Organization (WHO) 15 .

The independent variables were grouped in sociodemographic and behavioral variables, and health self-assessment. The evaluation included sex (male and female), age, marital status (with or without a spouse), schooling ( 0 to 4 ; 5 to 8 ; 9 to 12 ; and more than 12 years of school education), family income (in multiples of the minimum wage: up to 2; between 2 and 5; and more than 5), smoking habits (non-smoker, former smoker, smoker), alcohol consumption (never or very seldom drinks alcoholic beverages; drinks alcoholic beverages once or twice a week; drinks alcoholic beverages 3 to 7 times a week), food intake: meat fat and chicken skin (eat or not); beans (less than 5 or between 5 and 7 times a week); milk (does not drink, drinks whole milk, or drinks reduced-fat or fat-free milk); fruits and vegetables consumption (less than 5 or between 5 and 7 times a week); soft drinks (does not drink, drinks the regular one/any kind, or drinks the diet kind - referred as light, diet or sugar-free), and habit of sweetening drinks (does not sweeten/ uses artificial sweetener or uses sugar /sugar and artíficial sweetener), leisure-time physical activity (active or inactive, considering 150 minutes/week of mild, moderate, or strenuous activities, according to the WHO 16), and health self-assessment (very good to good; fair, and poor to very poor).

The context variable, income of the census tracts, classified in terciles, was obtained from the ratio between the total nominal monthly income of permanent private households and the total population of each census tract, both information available from the 2010 census 17 .

\section{Data analysis}

Overweight prevalence and 95\% confidence interval $(95 \% \mathrm{CI})$ were estimated according to individual and context variables, stratified per sex. The association was ascertained using Pearson's chisquare test $\left(\chi^{2}\right)$. All variables with $\mathrm{p}$-value $\mathrm{p} \leq 0.20$ were considered pertinent to be included in the multivariate model. For the selection of variables, the stepwise backward procedure was used, and in the final multivariate model variables with $\mathrm{p}$ value $<0.05$ remained, with the exception of age and census tract income, that were considered relevant for the outcome. Multilevel logistic regression was used (level 1: individual variables; level 2: census tract income variable), using a randomintercept, fixed effect model with logit function to calculate odds ratios (OR) and 95\%CI. The Akaike information criterion (AIC) was used for model comparison.

All analyses were made with the use of the software Stata, version 12 (StataCorp LP, College
Station, United States). The complexity of the sample design was considered in all analyses.

This study was approved by the Ethics in Research Committee, School of Medicine, Federal University of Minas Gerais (ETIC 253/06). All the interviewees were informed about the objectives of the research and signed the Informed Consent Form, agreeing in participating of the study.

\section{Results}

From the total of 3,129 subjects with age ranging from 20 and 60 years, 47 were excluded for lack of anthropometric measurements, and 98 for presenting BMI values lower than $18.5 \mathrm{~kg} / \mathrm{m}^{2}$. In addition, 49 residents in two of the 149 census tracts were also excluded for lack of information on per capita income. Thus, the final sample of this study included 2,935 residents.

Of these, $52.3 \%$ were females. The mean age for women was of 38.3 years $( \pm 11.5)$, and for man, 37.3 years $( \pm 11,4)$. Global prevalence for overweight was of $52.3 \%$ (95\%CI: 49.9-54.8), being similar between men and women, of respectively $52.9 \%$ (95\%CI: $49.5-56.2)$ and $51.8 \%$ (95\%CI: 48.2-55.4) ( $\mathrm{p}=0.69)$.

In the univariate analysis, all variables remained associated ( $p \leq 0.20$ ), except alcohol intake for both sexes, and intake of fats, fruits and vegetables consumption greens and vegetables, smoking, family income, and census tract income for women (Tables 1 and 2).

In the final model adjusted for females, reporting of soft drink intake was positively associated to overweight, regardless of the type of soft drink consumed. Women who reported drinking all types of soft drinks or the regular kind had a chance 1.65 higher of presenting overweight / obesity, and this chance increased to 2.64 among those who reported drinking diet soft drinks. Increase in age $(\mathrm{OR}=1.04 ; 95 \% \mathrm{CI}$ : $1.03-1.06)$, with a spouse $(\mathrm{OR}=1.38$; 95\%CI: $1.05-1.82)$, and health self-assessment rated as fair $(\mathrm{OR}=1.79 ; 95 \% \mathrm{CI}$ : $1.25-2.57$ ), or poor/very poor $(\mathrm{OR}=3.93$; $95 \% \mathrm{CI}$ : 1.78-8.67), and reporting of not sweetening or using an artificial sweetener $(\mathrm{OR}=1.61$; 95\%CI: 1.06 2.46) increased the chance of being overweight. Schooling (between 9 and 12 years of school education: $\mathrm{OR}=0.65$; $95 \% \mathrm{CI}$ : $0.43-0.99$; more than 12 years: $\mathrm{OR}=0.44 ; 95 \% \mathrm{CI}$ : $0.27-0.71$ ) was inversely associated with overweight (Table 3).

For males, in the adjusted final model, the following remained associated with overweight: drinking of diet soft drink $(\mathrm{OR}=3.16$; $95 \% \mathrm{CI}$ : 1.15-8.71), living with a spouse $(\mathrm{OR}=1.94$; 95\%CI: 1.28-2.95), health self-assessment rated poor/very poor $(\mathrm{OR}=2.21 ; 95 \% \mathrm{CI}$ : $1.05-4.66)$, 
Univariate analysis between overweight and sociodemographic variables in adults age 20 to 60 years in two health districts of Belo Horizonte, Minas Gerais State, Brazil. The BH Health Study, 2008-2009.

\begin{tabular}{|c|c|c|c|c|c|c|c|c|}
\hline \multirow[t]{2}{*}{ Variables } & \multicolumn{4}{|c|}{ Men } & \multicolumn{4}{|c|}{ Women } \\
\hline & $\mathbf{n}$ & Prevalence & $95 \% \mathrm{Cl}$ & $\mathrm{p}$-value & $\mathbf{n}$ & Prevalence & $95 \% \mathrm{Cl}$ & $\mathrm{p}$-value \\
\hline \multicolumn{9}{|l|}{ Age (years) } \\
\hline $20-29$ & 333 & 38.2 & $31.4-45.0$ & $<0.001$ * & 387 & 31.2 & $24.4-37.9$ & $<0.001$ * \\
\hline $30-39$ & 304 & 58.5 & $51.2-65.8$ & & 434 & 54.4 & $48.9-59.8$ & \\
\hline $40-49$ & 306 & 55.3 & $47.7-62.8$ & & 458 & 58.7 & $52.4-64.9$ & \\
\hline $50-60$ & 277 & 66.8 & $59.5-74.0$ & & 436 & 69.3 & $63.1-75.5$ & \\
\hline \multicolumn{9}{|l|}{ Marital status } \\
\hline Whithout a spouse & 485 & 42.6 & $36.9-48.3$ & $<0.001$ * & 789 & 45.3 & $40.5-50.1$ & $<0.001 *$ \\
\hline With a spouse & 735 & 61.6 & $57.0-66.2$ & & 926 & 57.4 & $52.6-62.3$ & \\
\hline \multicolumn{9}{|l|}{ Schooling (years) } \\
\hline $0-4$ & 205 & 53.8 & $45.8-61.9$ & 0.081 & 361 & 70.0 & $64.4-75.6$ & $<0.001$ * \\
\hline $5-8$ & 301 & 50.0 & $42.9-57.2$ & & 412 & 59.0 & $52.8-65.2$ & \\
\hline $9-12$ & 477 & 49.0 & $42.5-55.4$ & & 625 & 46.8 & $40.3-53.3$ & \\
\hline$>12$ & 237 & 61.2 & $53.5-68.9$ & & 315 & 40.4 & $33.9-46.8$ & \\
\hline \multicolumn{9}{|l|}{ Family income } \\
\hline \multicolumn{9}{|c|}{ (multiples of minimum wage) } \\
\hline$\leq 2$ & 219 & 42.6 & $33.5-51.7$ & 0.005 * & 492 & 55.1 & $49.0-61.1$ & 0.556 \\
\hline$>2$ and $\leq 5$ & 591 & 50.7 & $45.7-55.7$ & & 771 & 50.9 & $46.1-55.7$ & \\
\hline$>5$ & 386 & 59.8 & $54.0-65.6$ & & 415 & 50.9 & $44.3-57.6$ & \\
\hline \multicolumn{9}{|l|}{ Census tract income } \\
\hline 1st.tercile & 464 & 44.7 & $39.1-50.2$ & 0.003 * & 635 & 52.2 & $45.6-58.9$ & 0.739 \\
\hline 2nd.tercile & 407 & 56.0 & $50.1-61.8$ & & 613 & 53.3 & $48.4-58.1$ & \\
\hline 3rd.tercile & 349 & 57.9 & $52.1-63.7$ & & 467 & 49.9 & $42.8-57.0$ & \\
\hline
\end{tabular}

95\% Cl: 95\% confidence interval.

* Pearson's chi-square test significant at $5 \%$.

schooling (more than 12 years of school education: $\mathrm{OR}=2.23 ; 95 \% \mathrm{CI}: 1.08-4.58)$, smoking (smoker: OR = 0.49; 95\%CI: 0.31-0.76) and leisure-time physical activity (being active: $\mathrm{OR}=$ 0.55; 95\%CI: 0.36-0.83) (Table 4).

The context variable - census tract income - was statistically significant for the male model only (Table 4), in which subjects residing in tracts with higher per capita income terciles had higher chance of being overweight.

The most parsimonious model for males was the one that included census tract income whereas for females the best model was the one that included only individual variables.

\section{Discussion}

Overweight was prevalent in half of the adults residing in a urban area of Belo Horizonte, regardless of sex. While higher schooling was seen as a protective factor of overweight in women, and as a risk factor for men, residing in higher income census tracts was associated only for males. The reporting of drinking diet soft drinks was positively associated with overweight in both sexes.

It is to be noted that the occurrence of overweight is similar to that observed by the House hold Budgets Survey in 2008-2009 5, the same period of time that The BH Health Study was carried out. It is also similar to the findings of other national studies, that indicated that overweight affects about half of the population 18,19,20. These results may indicate the external validity of our investigation.

The association between overweight and socioeconomic indicators was different between men and women in our study, in accordance with the current literature 19,21,22,23,24,25. In our investigation, schooling was protective for women and a risk factor for men, similarly to other studies. 
Univariate analysis between overweight and behavioral variables and health self-assessment in adults age 20 to 60 years, in two health districts of Belo Horizonte, Minas Gerais State, Brazil. The BH Health Study, 2008-2009.

\begin{tabular}{|c|c|c|c|c|c|c|c|c|}
\hline \multirow[t]{2}{*}{ Variables } & \multicolumn{4}{|c|}{ Men } & \multicolumn{4}{|c|}{ Women } \\
\hline & $\mathbf{N}$ & Prevalence & $95 \% \mathrm{Cl}$ & $p$-value & $\mathbf{n}$ & Prevalence & $95 \% \mathrm{Cl}$ & $p$-value \\
\hline \multicolumn{9}{|l|}{ Smoking } \\
\hline No & 609 & 53.1 & $47.9-58.2$ & $<0.001$ * & 1.066 & 49.9 & $45.6-54.3$ & 0.207 \\
\hline Former smoker & 323 & 63.8 & $56.5-71.0$ & & 350 & 56.3 & $49.3-63.3$ & \\
\hline Smoker & 288 & 40.9 & $33.3-48.5$ & & 299 & 54.8 & $47.0-62.5$ & \\
\hline \multicolumn{9}{|l|}{ Alcohol intake } \\
\hline Never/seldom & 641 & 51.6 & $45.7-57.5$ & 0.388 & 1.323 & 53.1 & $49.2-57.0$ & 0.237 \\
\hline 1-2 days a week & 400 & 56.2 & $49.4-63.1$ & & 333 & 49.5 & $41.0-57.9$ & \\
\hline 3-7 days a week & 179 & 47.7 & $38.2-57.2$ & & 59 & 38.3 & $21.5-55.0$ & \\
\hline \multicolumn{9}{|l|}{ Intake of fat } \\
\hline Does not eat & 664 & 56.3 & $50.7-61.9$ & 0.113 & 1.163 & 51.1 & $46.8-55.5$ & 0.503 \\
\hline Eats & 508 & 50.1 & $45.3-54.8$ & & 427 & 53.3 & $48.0-58.7$ & \\
\hline \multicolumn{9}{|l|}{ Beans } \\
\hline Up to 5 days a week & 103 & 62.4 & $48.1-76.7$ & 0.198 & 329 & 46.6 & $38.7-54.5$ & 0.119 \\
\hline 5-7 days a week & 1,117 & 52.0 & $48.2-55.7$ & & 1.386 & 53.1 & $49.3-56.9$ & \\
\hline \multicolumn{9}{|l|}{ Milk } \\
\hline Does not drink & 369 & 46.6 & $39.9-53.3$ & 0.029 * & 547 & 53.4 & $47.1-59.6$ & 0.048 * \\
\hline Drinks whole milk & 733 & 53.7 & $48.9-58.5$ & & 892 & 48.2 & $43.1-53.3$ & \\
\hline $\begin{array}{l}\text { Drinks reduced fat/ } \\
\text { fat-free milk }\end{array}$ & 118 & 64.4 & $53.8-75.0$ & & 275 & 60.3 & $51.9-68.7$ & \\
\hline \multicolumn{9}{|l|}{ Fruits and vegetables } \\
\hline \multicolumn{9}{|l|}{ consumption } \\
\hline Up to 5 days a week & 723 & 48.4 & $43.7-52.9$ & 0.008 * & 794 & 51.3 & $46.4-56.2$ & 0.760 \\
\hline 5-7 days a week & 497 & 58.8 & $53.2-64.4$ & & 921 & 52.3 & $47.6-57.0$ & \\
\hline \multicolumn{9}{|l|}{ Intake of soft drink } \\
\hline Does not drink & 96 & 55.6 & $41.8-69.5$ & $<0.001$ * & 233 & 47.0 & $37.8-56.2$ & 0.073 \\
\hline $\begin{array}{l}\text { Drinks the regular one/all } \\
\text { kinds }\end{array}$ & 1,015 & 48.9 & $45.3-52.6$ & & 1244 & 50.9 & $47.0-54.7$ & \\
\hline Drinks diet/light/sugar-free & 108 & 82.7 & $73.9-91.6$ & & 235 & 61.3 & $51.3-71.4$ & \\
\hline \multicolumn{9}{|l|}{ Form of sweetening } \\
\hline Uses sugar and others & 1,057 & 49.2 & $45.3-53.0$ & $<0.001$ * & 1.380 & 49.8 & $46.2-53.3$ & 0.039 * \\
\hline $\begin{array}{l}\text { Does not sweeten and/or } \\
\text { uses sweetener }\end{array}$ & 163 & 71.2 & $62.1-80.2$ & & 335 & 59.6 & $50.6-68.5$ & \\
\hline \multicolumn{9}{|l|}{ Leisure-time physical activity } \\
\hline Inactive & 770 & 56.7 & $52.2-61.2$ & 0.060 & 1.240 & 53.5 & $49.4-57.7$ & 0.124 \\
\hline Active & 373 & 47.7 & $40.2-55.3$ & & 364 & 46.9 & $39.3-54.5$ & \\
\hline \multicolumn{9}{|l|}{ Health self-assessment } \\
\hline Very good/Good & 895 & 49.9 & $45.9-53.9$ & 0.003 * & 1.124 & 44.7 & $40.3-49.1$ & $<0.001$ * \\
\hline Fair & 268 & 61.1 & $53.4-68.8$ & & 490 & 64.8 & $58.2-71.4$ & \\
\hline Poor/Very poor & 57 & 70.5 & $56.8-84.3$ & & 100 & 80.2 & 70.9-89.6 & \\
\hline
\end{tabular}

95\% $\mathrm{Cl}: 95 \%$ confidence interval.

* Pearson's chi-square test significant at $5 \%$. 
Multivariate analysis between overweight and sociodemographic and behavioral variables, and health self-assessment in female adults, age 20 to 60 years in two health districts of Belo Horizonte, Minas Gerais State, Brazil. The BH Health Study, 2008-2009.

\begin{tabular}{|c|c|c|c|c|c|c|}
\hline \multirow[t]{2}{*}{ Variables } & \multicolumn{3}{|c|}{ Model 1 * } & \multicolumn{3}{|c|}{ Model $2 \star \star$} \\
\hline & OR & $95 \% \mathrm{Cl}$ & p-value & OR & $95 \% \mathrm{Cl}$ & p-value \\
\hline Age & 1.05 & $1.03-1.06$ & $<0.001$ & 1.04 & $1.03-1.06$ & $<0.001$ \\
\hline \multicolumn{7}{|l|}{ Marital status } \\
\hline Whithout a spouse & 1.00 & & - & 1.00 & & - \\
\hline With a spouse & 1.38 & $1.04-1.82$ & 0.024 & 1.38 & $1.05-1.82$ & 0.023 \\
\hline \multicolumn{7}{|l|}{ Schooling (years) } \\
\hline $0-4$ & 1.00 & & - & 1.00 & & - \\
\hline $5-8$ & 0.82 & $0.57-1.18$ & 0.287 & 0.81 & $0.55-1.19$ & 0.281 \\
\hline $9-12$ & 0.66 & $0.44-0.99$ & 0.045 & 0.65 & $0.43-0.99$ & 0.047 \\
\hline$>12$ & 0.45 & $0.29-0.70$ & $<0.001$ & 0.44 & $0.27-0.71$ & 0.001 \\
\hline \multicolumn{7}{|l|}{ Form of sweetening } \\
\hline Uses sugar and others & 1.00 & & - & 1.00 & & - \\
\hline Does not sweeten and/or uses sweetener & 1.61 & $1.06-2.46$ & 0.026 & 1.61 & $1.06-2.46$ & 0.027 \\
\hline \multicolumn{7}{|l|}{ Health self-assessment } \\
\hline Very good/Good & 1.00 & & - & 1.00 & & - \\
\hline Fair & 1.79 & $1.25-2.56$ & 0.002 & 1.79 & $1.25-2.57$ & 0.002 \\
\hline Poor/Very poor & 3.91 & $1.78-8.56$ & 0.001 & 3.93 & $1.78-8.67$ & 0.001 \\
\hline \multicolumn{7}{|l|}{ Intake of soft drink } \\
\hline Does not drink & 1.00 & & - & 1.00 & & - \\
\hline Drinks the regular one/all kinds & 1.65 & $1.03-2.65$ & 0.038 & 1.65 & $1.03-2.65$ & 0.038 \\
\hline Drinks diet/light/sugar-free & 2.64 & $1.39-5.03$ & 0.003 & 2.64 & $1.39-5.01$ & 0.003 \\
\hline \multicolumn{7}{|l|}{ Census tract income } \\
\hline 1st.tercile & & & & 1.00 & & - \\
\hline 2nd.tercile & & & & 1.08 & $0.73-1.57$ & 0.710 \\
\hline 3rd.tercile & & & & 1.07 & $0.68-1.68$ & 0.770 \\
\hline Variance (covariance) & \multicolumn{3}{|c|}{$0.348(0.113)$} & \multicolumn{3}{|c|}{$0.346(0.113)$} \\
\hline $\mathrm{AlC}$ & \multicolumn{3}{|c|}{2015.19} & \multicolumn{3}{|c|}{2019.02} \\
\hline
\end{tabular}

95\% Cl: 95\% confidence interval; AIC: Akaike information criterion; OR: odds ratio.

* Model 1: individual variables-adjusted model;

** Modelo 2: individual and context variables-adjusted model.

Census tract income was positively associated with overweight only for males. For them, the association of schooling and census tract income with overweight could be ascribed to their occupational activities. The majority of men with schooling of more than 12 years and residing in tracts with higher income terciles perform sedentary activity $(72.9 \%$ and $54.6 \%$, respectively) (data not shown). For women with higher schooling, possible explanations are stronger social pressures and more access to weight control and loss strategies, whether healthy or not $26,27,28$. In the Brazilian literature, no studies have investigated overweight, individual and context factors at the same time.
Regarding the association found between the reported drinking of diet soft drinks and overweight, the cross-sectional nature of the study does not allow a timeline to be established, as the possible determining factors and the outcome were evaluated simultaneously. However, recent prospective, experimental studies corroborate this finding 29,30,31,32,33,34, and the possible unhealthy effects of diet soft drinks have been discussed, in addition to a lack of consensus on their safety to drink 35,36 .

This finding might have been influenced by reverse causality, since, once body overweight is diagnosed, the individual could have started caloric restriction methods in order to control 
Multivariate analysis between overweight and sociodemographic and behavioral variables and health self-assessment in male adults, age 20 to 60 years in two health districts of Belo Horizonte, Minas Gerais State, Brazil. The BH Health Study, 2008-2009.

\begin{tabular}{|c|c|c|c|c|c|c|}
\hline \multirow[t]{2}{*}{ Variables } & \multicolumn{3}{|c|}{ Model 1} & \multicolumn{3}{|c|}{ Model 2} \\
\hline & OR & $95 \% \mathrm{Cl}$ & $\mathrm{p}$-value & OR & $95 \% \mathrm{Cl}$ & $p$-value \\
\hline Age & 1.02 & $1.00-1.04$ & 0.048 & 1.02 & $1.00-1.04$ & 0.084 \\
\hline \multicolumn{7}{|l|}{ Marital status } \\
\hline Without a spouse & 1.00 & & - & 1.00 & & - \\
\hline With spouse & 1.93 & $1.27-2.95$ & 0.002 & 1.94 & $1.28-2.95$ & 0.002 \\
\hline \multicolumn{7}{|l|}{ Schooling (years) } \\
\hline $0-4$ & 1.00 & & - & 1.00 & & - \\
\hline $5-8$ & 1.25 & $0.76-2.07$ & 0.384 & 1.18 & $0.71-1.96$ & 0.524 \\
\hline $9-12$ & 1.58 & $0.94-2.65$ & 0.085 & 1.39 & $0.82-2.34$ & 0.220 \\
\hline$>12$ & 2.86 & $1.46-5.59$ & 0.002 & 2.23 & $1.08-4.58$ & 0.030 \\
\hline \multicolumn{7}{|l|}{ Smoking } \\
\hline No & 1.00 & & - & 1.00 & & - \\
\hline Former smoker & 1.51 & $0.97-2.35$ & 0.065 & 1.49 & $0.96-2.29$ & 0.074 \\
\hline Smoker & 0.51 & $0.33-0.80$ & 0.003 & 0.49 & $0.31-0.76$ & 0.002 \\
\hline \multicolumn{7}{|l|}{ Leisure-time physical activity } \\
\hline Inactive & 1.00 & & - & 1.00 & & - \\
\hline Active & 0.56 & $0.37-0.87$ & 0.009 & 0.55 & $0.36-0.83$ & 0.004 \\
\hline \multicolumn{7}{|l|}{ Health self-assessment } \\
\hline Very good/Good & 1.00 & & - & 1.00 & & - \\
\hline Fair & 1.44 & $0.92-2.26$ & 0.111 & 1.47 & $0.94-2.28$ & 0.089 \\
\hline Poor/Very poor & 2.17 & $1.01-4.64$ & 0.046 & 2.21 & $1.05-4.66$ & 0.037 \\
\hline \multicolumn{7}{|l|}{ Intake of soft drink } \\
\hline Does not drink & 1.00 & & - & 1.00 & & - \\
\hline Drinks the regular one/all kinds & 0.68 & $0.33-1.41$ & 0.301 & 0.70 & $0.35-1.41$ & 0.317 \\
\hline Drinks diet/light/sugar-free & 3.27 & $1.16-9.21$ & 0.025 & 3.16 & $1.15-8.71$ & 0.026 \\
\hline \multicolumn{7}{|l|}{ Census tract income } \\
\hline 1st tercile & & & & 1.00 & & - \\
\hline 2nd tercile & & & & 1.69 & $1.18-2.43$ & 0.004 \\
\hline 3rd tercile & & & & 1.82 & $1.18-2.80$ & 0.007 \\
\hline Variance (covariance) & & $0.256(0.109)$ & & & $0.209(0.095)$ & \\
\hline $\mathrm{AIC}$ & & 1737.85 & & & 1731.00 & \\
\hline
\end{tabular}

95\% Cl: 95\% confidence interval; AIC: Akaike information criterion; OR: odds ratio.

morbidity. However, the association between drinking diet soft drinks and weight gain seems plausible, even though empirical data do not support these hypotheses universally. It has been suggested that excessive intake of other food or drinks may occur along with the intake of these diet soft drinks 37 , through a mechanism called caloric compensation, this means, a person believes that due to the intake of some diet food they are allowed to have other food with more calories ${ }^{31}$. This discussion is supported by findings of some authors, who observed that the intake of diet soft drinks is positively associated with the intake of highly caloric, unhealthy food that can cause overweight and obesity 38 .
In addition, the hypothesis that artificial sweeteners may increase craving for sweets and energy-dense foods 30,33,38,39,40,41 was raised. Therefore, the association, between diet soft drink intake and overweight seems plausible beyond reverse causality.

Another possible explanation for this relation is social desirability and intentional falsehood, which occurs when individuals tend to report eating food publicized as healthy, when in fact they do not. This bias is frequently observed in population studies about food intake ${ }^{42}$, particularly among women and overweight individuals $43,44,45$, but found no grounds in our study, since we did not find an association in the reporting of 
fruits and vegetables consumption by overweight women $(\mathrm{OR}=1.06$; 95\%CI: 0.82-1.38), which weakens this possibility.

It is worth mentioning that, regardless of the hypotheses raised, the fact is that overweight individuals report the intake of diet soft drinks and other food. Considering the importance of this finding for public health, it is worth discussing here the possible consequences over this current behavior, particularly considering that these foods typically have higher amounts of sodium. Furthermore, a study recently published 46 found that the use of artificial sweeteners increased the risk of glucose intolerance in animals and in a small set of humans, with this alteration measured by the intestinal microbiota composition modulation and function. Thus, despite an intense marketing in the media for the use of diet products, caution is warranted, particularly by those individuals with high blood pressure and glucose-intolerance/diabetes, which are morbid conditions known to be related to overweight.

In women, association was also made with the intake of non-diet soft drinks. There is no question that the high intake of beverages, particularly those sweetened with sugar, like soft drinks, has been considered by researchers as one of the possible factors associated with weight gain, in a number of countries and for different age groups, this being ascribed to their caloric content and their effect on satiety mechanisms. The potential mechanisms involved in the hypothesis that liquid food satiate less than solid food are the lack of mastication, less pronounced food-intake cephalic phase, and faster gastric voiding, leading individuals to a higher energy intake 47 . Moreover, sweetened beverages present high glycemic index, causing a chronic state of hyperglicemia and hyperinsulinemia, with the consequent gain in weight and body fat 48 .

Other variables that remained associated with overweight in women, such as age and living with a spouse may be explained by metabolic and behavioral mechanisms, such as hormonal alterations, parity, a more sedentary lifestyle, and less intense physical activities. Living with a spouse was also associated with overweight in men 22,49,50.

Smoking remained associated for men, and it seems that smokers would be less disposed to excessive weight gain, possibly due to the thermogenic effect of nicotine, that also suppresses the appetite 51,52. Conversely, the same association was not found in women.

The protective effect of non-competitive physical activity, found only in men, may be explained by the intensity of the activities listed in The BH Health Study for each sex; women re- port practicing more activities such as stretching, aqua fitness and walking, whereas men prefer more strenuous exercises, such as running, weight workout, and cycling (data not shown).

Health self-perception is how individuals assess their own health. This indicator seems to show that women are more careful with their own health and with prevention of diseases, as they reported their health as being fair, poor and very poor, while for men only the last two categories remained associated.

Before drawing the final conclusions of this study, one should discuss its limitations. Being a cross-sectional study, any causal relation between exposure and outcome cannot be directly indentified or interpreted, as already discussed in regards to the association found between overweight and drinking of diet soft drinks and the use of sweeteners.

As to the inference ability of the study for the city of Belo Horizonte, it should be stressed that the two districts investigated account for $24 \%$ of the city's population 17 , and even though the collected sample do not necessarily reflect the city, the census tracts included allowed the city's socioeconomic inequalities to be included.

In addition, it is worth mentioning the limitations of the food-intake assessment, as measurements were based on a categorized, self-referred way, which is typical of population surveys.

Despite the limitations, it is worth mentioning the strengths of the study. Besides the relative potentiality regarding the size of the sample, the survey was intended for a multilevel analysis, and the questionnaire presents questions of good reproducibility 13 . In addition, the dependent variable of the study, overweight, used measured weight and height, which is another advantage of the study. Worthy of note is the fact that other population surveys use self-referred weight and height to calculate BMI and to define the nutritional state.

In conclusion, this study helped to demonstrate that overweight-related factors were different between sexes, which indicate that this alteration of the nutritional state in men and women may be influenced by distinct factors, or may be inter-related in a different way. The findings contribute to a better understanding of the complex interaction among the overweight-related factors for both sexes, and may play an important role in the development of effective interventions, and in the expansion of obesity-control programs in urban centers, like Belo Horizonte.

In regards to the intake of diet food, given the possible limitations of the study, and considering the somewhat scarce evidence in the literature, one recommends considering the Principle 
of Precaution, as this is an evitable or unnecessary exposure. According to this principle, the intake or use of any product or substance whose adverse effect is not completely clear, and the lack of scientific consensus that its exposure may be potentially hazardous leads to discouraging its use, except if there are specific conditions in which the risk-benefit ratio justifies the exposure 35 . It is thus necessary that users seek pro- fessional guidance, and that health practitioners are knowledgeable enough to provide proper guidance on the use of such products.

Furthermore, prospective studies, and studies that use other methodological approaches considering the frequency and quantity of sweetener consumption and diet food intake should be encouraged, particularly if one considers their popularity and the increasing consumption.

\section{Resumen}

El presente estudio se propuso evaluar los factores asociados con el sobrepeso en los adultos que viven en zonas urbanas, utilizando los ingresos de la circunscripción censal como variable de contexto. La encuesta evaluó los individuos de dos distritos de salud de Belo Horizonte, Minas Gerais, Brasil. El exceso de peso se determinó mediante el índice de masa corporal $>25 \mathrm{~kg} /$ $m^{2}$. Se utilizó la regresión logística multinivel. La muestra está formada por 2.935 individuos de 20 a 60 años de edad. La prevalencia de sobrepeso fue de un 52,3\% (IC95\%: 49,9-54,8), similar entre hombres y mujeres. Mientras que la escolarización ha demostrado tener un efecto protector contra el sobrepeso en las mujeres, en el caso sólo de los hombres, sí mostro riesgo asociado, pese a que vivieran en las circunscripciones censales con ingresos más altos. El consumo de refrescos dietéticos se asoció positivamente con el sobrepeso en ambos sexos. La ocurrencia de este evento parece estar influida por diferentes factores o se interrelacionan de manera diferente en hombres y mujeres.

Obesidad; Renta; Factores Socioeconómicos; Salud Urbana

\section{Contributors}

R. G. Andrade and O. C. Chaves participated in data interpretation, preparation of the manuscript, relevant critical review of the contents, and approval of the final version of the manuscript. D. A. S. Costa and A. C. S. Andrade participated in data analysis and interpretation, relevant critical review of the contents, and approval of the final version of the manuscript. S. Bispo participated in data analysis and interpretation, preparation of the manuscript and approval of the final version of the manuscript. M. F. Felicissimo participated in the approval of the final version of the manuscript. A. A. L. Friche participated in the study design and approval of the final version of the manuscript. F. A. Proietti and C. C. Xavier participated in the project design and planning, and in the approval of the final version of the manuscript. W. T. Caiaffa participated in the project design and planning, data interpretation, preparation of the manuscript, relevant critical review of the contents, and approval of the final version of the manuscript.

\section{Acknowledgments}

To all investigators of the Belo Horizonte Observatory for Urban Health who took part in The BH Health Stu$d y$, and to the City Health Secretariat of Belo Horizonte for its support in data collection. Financial support was given by the Ministry of Health's National Health Fund, Fapemig, CNPq and NIH/Fogarty International Center. Additional funding was provided by $\mathrm{CNPq}$ as a research grant to the author W. T. Caiaffa. 


\section{References}

1. World Health Organization. Obesity and overweight 2013. http://www.who.int/mediacentre/ factsheets/fs311/en (accessed on Apr/2014).

2. Ogden CL, Carroll MD, Kit BK, Flegal KM. Prevalence of childhood and adult obesity in the United States, 2011-2012. JAMA 2014; 311:806-14.

3. Popkin BM, Slining MM. New dynamics in global obesity facing low- and middle-income countries. Obes Rev 2013; 14 Suppl 2:11-20.

4. Robles B, Frost S, Moore L, Harris CV, Bradlyn AS, Kuo T. Overweight and obesity among low-income women in rural West Virginia and urban Los Angeles County. Prev Med; in press.

5. Instituto Brasileiro de Geografia e Estatística. Pesquisa de Orçamentos Familiares - 2008-2009. Antropometria e estado nutricional de crianças, adolescentes e adultos no Brasil. Rio de Janeiro: Instituto Brasileiro de Geografia e Estatística; 2010.

6. Speakman JR, O'Rahilly S. Fat: an evolving issue. Dis Model Mech 2012; 5:569-73.

7. World Health Organization. The challenge of obesity in the WHO European Region and the strategies for response. Copenhagen: World Health Organization; 2007.

8. Vieira ACR, Sichieri R. Associação do status socioeconômico com obesidade. Physis (Rio J.) 2008; 18:415-26

9. Bodor JN, Rice JC, Farley TA, Swalm CM, Rose D. The association between obesity and urban food environments. J Urban Health 2010; 87:771-81.

10. Morland KB, Evenson KR. Obesity prevalence and the local food environment. Health Place 2009; 15:491-5.

11. Giskes K, van Lenthe F, Avendano-Pabon M, Brug J. A systematic review of environmental factors and obesogenic dietary intakes among adults: are we getting closer to understanding obesogenic environments? Obes Rev 2011; 12:e95-e106.

12. McLaren L. Socioeconomic status and obesity. Epidemiol Rev 2007; 29:29-48.

13. Ferreira AD, Comini CC, Malta DC, Andrade ACS, Ramos CGC, Proietti FA, et al. Validity of data collected by telephone survey: a comparison of VIGITEL 2008 and 'Saúde em Beagá' survey. Rev Bras Epidemiol 2011; 14:16-30.

14. Camargos VP, César CC, Caiaffa WT, Xavier CC, Proietti FA. Imputação múltipla e análise de casos completos em modelos de regressão logística: uma avaliação prática do impacto das perdas em covariáveis. Cad Saúde Pública 2011; 27:2299-313.

15. World Health Organization. Physical status: the use and interpretation of anthropometry. Report of a WHO Expert Committee. Geneva: World Health Organization; 1995.

16. World Health Organization. Global recommendations on physical activity for health. Geneva: World Health Organization; 2011.

17. Instituto Brasileiro Geografia e Estatística. Sinopse do Censo Demográfico 2010. Rio de Janeiro: Instituto Brasileiro de Geografia e Estatística; 2011.
18. Departamento de Análise de Situação de Saúde Secretaria de Vigilância em Saúde, Ministério da Saúde. Vigitel Brasil 2012: vigilância de fatores de risco e proteção para doenças crônicas por inquérito telefônico. Brasília: Ministério da Saúde; 2013.

19. Pinho CPS, Diniz AS, Arruda IKG, Lira PIC, Sequeira LAS, Gonçalves FCLSP, et al. Excesso de peso em adultos do Estado de Pernambuco, Brasil: magnitude e fatores associados. Cad Saúde Pública 2011; 27:2340-50.

20. Gigante DP, Dias-da-Costa JS, Olinto MTA, Menezes AMB, Macedo S. Obesidade da população adulta de Pelotas, Rio Grande do Sul, Brasil e associação com nível sócio-econômico. Cad Saúde Pública 2006; 22:1873-9.

21. Fonseca MJM, Faerstein E, Chor D, Lopes CS, Andreozzi VL. Associações entre escolaridade, renda e Índice de Massa Corporal em funcionários de uma universidade no Rio de Janeiro, Brasil: estudo Pró-Saúde. Cad Saúde Pública 2006; 22:2359-67.

22. Gigante DP, Moura EC, Sardinha LMV. Prevalência de excesso de peso e obesidade e fatores associados, Brasil, 2006. Rev Saúde Pública 2009; 43:83-9.

23. Kawachi I, Adler NE, Dow WH. Money, schooling, and health: mechanisms and causal evidence. Ann NY Acad Sci 2010; 1186:56-68.

24. Monteiro CA, Conde WL, Popkin BM. Independent effects of income and education on the risk of obesity in the Brazilian adult population. J Nutr 2001; 131:881S-6S.

25. Vedana EHB, Peres MA, Neves J, Rocha GC, Longo GZ. Prevalência de obesidade e fatores potencialmente causais em adultos em região do sul do Brasil. Arq Bras Endocrinol Metab 2008; 52:1156-62.

26. Demuth A, Czerniak U, Ziolkowska-Lajp E. A comparison of a subjective body assessment of men and women of the Polish social elite. Homo 2013; 64:398-409.

27. McLaren L, Kuh D. Women's body dissatisfaction, social class, and social mobility. Soc Sci Med 2004; 58:1575-84.

28. Paquette MC, Raine K. Sociocultural context of women's body image. Soc Sci Med 2004; 59:104758.

29. Anderson GH, Foreyt J, Sigman-Grant M, Allison DB. The use of low-calorie sweeteners by adults: impact on weight management. J Nutr 2012; 142:1163s-9s

30. Bleich SN, Wolfson JA, Vine S, Wang YC. Diet-beverage consumption and caloric intake among US adults, overall and by body weight. Am J Public Health 2014; 104:e72-8.

31. Gardner C, Wylie-Rosett J, Gidding SS, Steffen LM, Johnson RK, Reader D, et al. Nonnutritive sweeteners: current use and health perspectives: a scientific statement from the American Heart Association and the American Diabetes Association. Diabetes Care 2012; 35:1798-808. 
32. Mattes RD, Popkin BM. Nonnutritive sweetene consumption in humans: effects on appetite and food intake and their putative mechanisms. Am J Clin Nutr 2009; 89:1-14.

33. Swithers SE. Artificial sweeteners produce the counterintuitive effect of inducing metabolic derangements. Trends Endocrinol Metab 2013; 24:431-41.

34. Swithers SE, Sample CH, Davidson TL. Adverse effects of high-intensity sweeteners on energy intake and weight control in male and obesity-prone female rats. Behav Neurosci 2013; 127:262-74.

35. Fagherazzi G, Vilier A, Saes Sartorelli D, Lajous M, Balkau B, Clavel-Chapelon F. Consumption of artificially and sugar-sweetened beverages and incident type 2 diabetes in the Etude Epidemiologique aupres des femmes de la Mutuelle Generale de l'Education Nationale-European Prospective Investigation into Cancer and Nutrition cohort. Am J Clin Nutr 2013; 97:517-23.

36. Shankar P, Ahuja S, Sriram K. Non-nutritive sweeteners: review and update. Nutrition 2013; 29: 1293-9.

37. Nettleton JA, Lutsey PL, Wang Y, Lima JA, Michos ED, Jacobs Jr. DR. Diet soda intake and risk of incident metabolic syndrome and type 2 diabetes in the Multi-Ethnic Study of Atherosclerosis (MESA). Diabetes Care 2009; 32:688-94.

38. Swithers SE, Martin AA, Davidson TL. High-intensity sweeteners and energy balance. Physiol Behav 2010; 100:55-62.

39. Green E, Murphy C. Altered processing of sweet taste in the brain of diet soda drinkers. Physiol Behav 2012; 107:560-7.

40. Rudenga KJ, Small DM. Amygdala response to sucrose consumption is inversely related to artificial sweetener use. Appetite 2012; 58:504-7.

41. Yang Q. Gain weight by “going diet?" Artificial sweeteners and the neurobiology of sugar cravings. Yale J Biol Med 2010; 83:101-8.

42. Lissner L. Measuring food intake in studies of obesity. Public Health Nutr 2002; 5:889-92.

43. Gomes AA, Leão LSCS. Prevalência de sub-relato e super-relato de ingestão energética em população ambulatorial do Rio de Janeiro, Brasil. Cad Saúde Colet (Rio J.) 2011; 19:197-202.
44. Macdiarmid J, Blundell J. Assessing dietary intake: who, what and why of under-reporting. Nutr Res Rev 1998; 11:231-53.

45. Avelino GF, Previdelli AN, Castro MA, Marchioni DML, Fisberg RM. Sub-relato da ingestão energética e fatores associados em estudo de base populacional. Cad Saúde Pública 2014; 30:663-8.

46. Suez J, Korem T, Zeevi D, Ziberman-Schapira G, Thaiss CA, Maza O, et al. Artificial sweeteners induce glucose intolerance by altering the gut microbiota. Nature 2014; 17:1-5.

47. Mourão DM, Bressan J. Influência de alimentos líquidos e sólidos no controle do apetite. Rev Nutr 2009; 22:537-47.

48. Vartanian LR, Schwartz MB, Brownell KD. Effects of soft drink consumption on nutrition and health: a systematic review and meta-analysis. Am J Public Health 2007; 97:667-75.

49. Veloso HJF, Silva AAM. Prevalência e fatores associados à obesidade abdominal e ao excesso de peso em adultos maranhenses. Rev Bras Epidemiol 2010; 13:400-12.

50. Machado IE, Pereira SCL, Dias Júnior CS, Abreu MNS, Borges AM, Filgueiras JH. Fatores associados ao excesso de peso em adultos usuários de restaurantes populares em Belo Horizonte, Brasil. Ciênc Saúde Coletiva 2014; 19:1367-77.

51. Berto SJP, Carvalhaes MABL, Moura EC. Tabagismo associado a outros fatores comportamentais de risco de doenças e agravos crônicos não transmissíveis. Cad Saúde Pública 2010; 26:1573-82.

52. Gonseth S, Jacot-Sadowski I, Diethelm PA, Barras V, Cornuz J. The tobacco industry's past role in weight control related to smoking. Eur J Public Health 2012; 22:234-7.

Submitted on 03/Jul/2014

Final version resubmitted on $07 /$ Oct/2014

Approved on 08/Oct/2014 